\title{
Public-private partnerships in basic service delivery: impact on the poor, examples from the water sector in India
}

\author{
Meine Pieter van Dijk \\ UNESCO-IHE Institute for Water Education, \\ PO Box 3015, 2601 DA Delft, The Netherlands \\ E-mail:m.vandijk@unesco-ihe.org
}

\begin{abstract}
What is the theory behind Public-Private Partnerships (PPPs)? In this contribution PPPs are defined as private sector involvement, where a public and a private partner share the risks related to the necessary investments. Besides complementarity, the other factors contributing to the success of PPPs will be analysed. Evidence concerning India will be used to assess which factors played a role and to suggest a PPP dialogue in India, which would involve all stakeholders before actually embarking on PPPs for urban infrastructure projects such as drinking water and sanitation. It would help to do projects in such a way that they would also benefit the urban poor.
\end{abstract}

Keywords: Public-Private Partnerships; PPP; basic service delivery; impact poor; water sector; India.

Reference to this paper should be made as follows: van Dijk, M.P. (2008), 'Public-private partnerships in basic service delivery: impact on the poor, examples from the water sector in India', Int. J. Water, Vol. 4, No. 3/4, pp.216-234.

\begin{abstract}
Biographical notes: Meine Pieter van Dijk is an Economist and Professor of Water Services Management at UNESCO-IHE Institute for Water Education in Delft and Professor of Urban Management at the Institute of Social Studies in The Hague, both in The Netherlands. He received his $\mathrm{PhD}$ in Economics from the Free University Amsterdam. He is member of the research schools CERES and SENSE. His recent books are Managing Cities in Developing Countries, the Theory and Practice of Urban Management (2006, Cheltenham: Edgar Elgar) and with C. Sijbesma (Eds, 2006) Water and Sanitation Institutional Challenges in India (New Delhi: Manohar).
\end{abstract}

\section{Introduction}

A substantial number of Public-Private Partnerships (PPPs) experiments were conducted in the water sector in the 1990s. They often concerned concession contracts (a long-term right to extract some natural resource on behalf of the government) and sometimes had a Build Operate Transfer (BOT) contract added to it to assure the necessary investments. These experiments generated a number of valuable lessons under which circumstances PPPs can be successful. 
India is changing rapidly. In urban areas in India efforts have been made to promote Private Sector Involvement (PSI) in infrastructure provision. The need for better water supply and sanitation in India can be translated in a demand for new sources of finance - particularly private sector finance, new methods of channelling finance to projects and new financial instruments (using bonds, project finance or issuing shares; van Dijk, 2006a). Billions of euros will be needed annually over the next 10 years to finance infrastructure investment in Asia alone, given increasingly urbanised populations and higher income levels. ${ }^{1}$ To achieve this requires a much greater involvement of the private sector on the one hand, but also more pro-active and innovative activities of the public sector on the other.

This contribution focuses on increasing the role of the private sector and of private finance in the urban infrastructure development process and its effects on the poor and on achieving the Millennium Development Goals (MDGs). PPP became more and more important and the Financial Institutions Reform and Expansion (FIRE) project has played a catalytic role supporting urban environmental infrastructure projects with private financial support in, for example, Andhra Pradesh, Gujarat, Maharashtra and Tamil Nadu. ${ }^{2}$ The question is what has been the impact of these PPPs on urban basic service delivery and in particular on service delivery for the urban poor in India?

In this contribution we first define PPPs and list what their strong and weak points are according to the literature. Subsequently, progress in India with PSI and in particular PPPs in urban infrastructure provision will be reviewed to provide the evidence. Finally, the link between PPP and poverty alleviation will be explored.

\section{Defining PPPs and why they would contribute}

Public-Private Partnership is an institutional arrangement often used in the infrastructure sector, including water and sanitation projects. Box 1 gives the definitions of PPP and Public-Private-Community Partnership (PPCP), which are often used. ${ }^{3}$ A PPCP or tri-party or tripartite agreement is a variation which was developed in Indonesia to counter some of the criticisms of the PPP concept. Usually, representatives from civil society would be included in such a partnership. The Webster dictionary defines partnerships as a legal relation existing between two or more persons contractually associated as joint principals in a business. ${ }^{4}$

\begin{tabular}{|ll|}
\hline Box $1 \quad$ Definitions of PPP and PPCP or tri-party agreements \\
\hline PPP & PPCP or tri-party agreement \\
$\begin{array}{ll}\text { A PPP implies cooperation between different } \\
\text { actors, usually one from the private and one }\end{array}$ & $\begin{array}{l}\text { A PPCP is a PPP in which the local } \\
\text { community is also one of the partners }\end{array}$ \\
$\begin{array}{l}\text { from the public sector, who work together to } \\
\text { promote a common interest, using the }\end{array}$ & $\begin{array}{l}\text { involved. Sometimes the community itself is } \\
\text { complementarities of the partners and their } \\
\text { special qualities. Both parties run a risk in the }\end{array}$ \\
$\begin{array}{ll}\text { project. } & \text { PPCP is used, for example for a small-scale } \\
\end{array}$ & water supply project. \\
\hline
\end{tabular}

PPPs can also be considered an alternative way of financing initiatives, which would otherwise not be realised. The term PPP is used for a large range of initiatives to involve the private sector, including financing through the private sector, or using money from private individuals (for examples bonds bought by them). The most important 
defining characteristics of PPPs are mentioned in Nijkamp et al. (2002, p.1869): 'a PPP is an institutionalised form of cooperation of public and private actors who:

1 on the basis of their own indigenous objectives work together

2 towards a joint target

3 in which both parties accept investment risks on the basis of pre-determined distribution of revenues and costs'.

In particular the element of risk sharing comes aback in the literature (for example Pongsiri, 2002; Jamali, 2004). Prasad (2006) gives a very different perspective. He considers PPP as repackaging privatisation and PSI. ${ }^{5}$ Then he goes on to characterise it as the robustness of the free market ideology, instead of trying to assess the evidence whether PPPs would be doing a better job than the other forms of privatisation distinguished. Burnham (2001) calls PPPs investment without an increase in public expenditures. That is too easy. If risks are involved, expenses may be at a later date, but they are still there. PPPs do require a local private sector to work with and eventually to take over from the foreign companies, which tend to be the first to be involved in the water sector.

Private Sector Involvement has a lot to do with market and government failures. However, it is not easy to establish competitive market structures (Kirkpatrick and Parker, 2004). Concerning the increasing role for the private sector and of PPPs in water, sanitation and urban development the question can be asked: what are the factors influencing the chance of success of PPPs in drinking water in developing countries? What are the arguments used to support PPPs in the provision of water and sanitation services since the 1980s? How can we regulate PPPs? Finally, the following question will be asked: what makes PPPs successful?

Franceys and Bos (2003) showed that the number of PPP contracts reported per year in middle and low-income countries increased from 4 in 1991 to 29 in 1999 and that number has only increased. By 2002 there were 106 water and sanitation projects in Latin America and the Caribbean and 73 in East Asia and the Pacific region, while only seven were counted in the Middle East and North Africa and 14 in Sub-Saharan Africa. ${ }^{6}$

It is expected that partnerships will create win-win situations. Expected benefits included providing access to private finance, better service provision, cost efficiencies and capitalising on the strong points of each sector. The PPP formula is usually chosen to deal with problems of high complexity (for example a water and sanitation provision in a slum upgrading project), or to carry out large-scale projects (for example a sewerage system for a whole city). The initiators hope to combine the effective mechanisms of the market with the support that can be expected from the government organisations involved. PPPs allow making maximum use of the characteristics of both the private and the public sector to create mutual benefits, as indicated in Table 1.

PPPs have become increasingly popular, because the formula suggests that the best elements of the private and public sector approach can be combined. However, there are a large number of very different options for PSI, which can only be judged by looking at the details of each arrangement. A distinction should be made between a legal form ${ }^{7}$ and different financial instruments, which can be used with such legal forms. ${ }^{8}$ 
Table 1 Strong and weak points of private and the public sector in PPPs

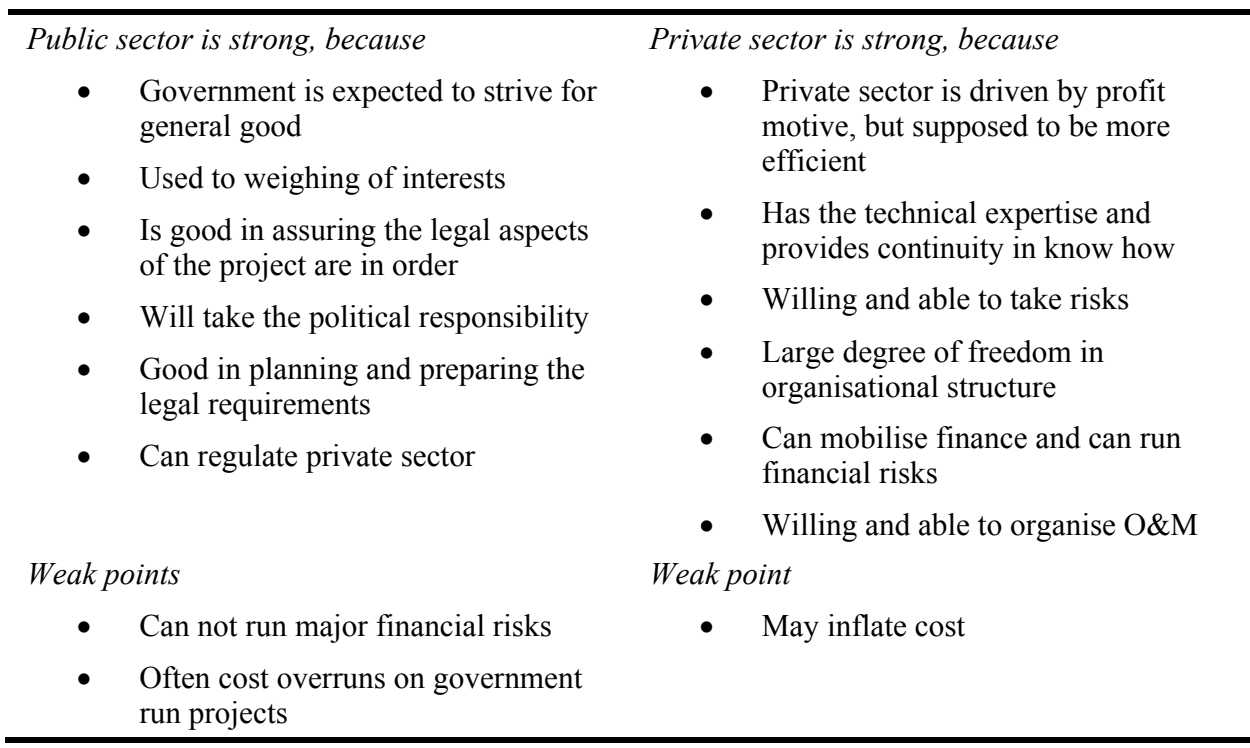

Public-Private Partnerships may be defined as cooperative ventures between a public entity and a private party, aiming to realise common projects in which they share risks, costs and profit. The following Table 2 provides the reasons are usually put forward to involve the private sector in water and sanitation and the (high) expectations of a PPP in this sector.

Table 2 Reasons for PSI in water and sanitation and expectations

\begin{tabular}{|c|c|}
\hline & ons \\
\hline $\begin{array}{l}\text { - } \text { Complicated projects } \\
\text { - } \text { Government has no money } \\
\text { - } \quad \text { Government failed to deliver the service in } \\
\text { the past } \\
\text { - } \quad \text { Substantial investment required } \\
\text { - } \quad \text { There are important time and cost overruns in } \\
\text { - } \text { government projects } \\
\text { - } \quad \text { Complementary expertise } \\
\text { - } \quad \text { Government can not run these risks } \\
\text { - } \quad \text { Lack of expertise in the field } \\
\text { - Introduce improved commercial management } \\
\text { - } \quad \text { Reduce political interventions in utility } \\
\text { operations } \\
\text { Reduce number of public sector employees } \\
\text { and associated obligations }\end{array}$ & $\begin{array}{l}\text { - Improve quality of service } \\
\text { - } \quad \text { Makequacy and reliability) } \\
\text { infrastructure } \\
\text { - } \quad \text { Improve operating efficiency and } \\
\text { system performance } \\
\text { - Achieve net savings in the costs of } \\
\text { service provision and reduce } \\
\text { subsidies } \\
\text { - Introduce competition in the sector } \\
\text { and act as a catalyst for change to } \\
\text { the wider public sector } \\
\text { - } \quad \text { Supply the required capital funding } \\
\text { by injecting private investment } \\
\text { capital (and efficiency in the use of } \\
\text { that capital) } \\
\text { Expand service coverage to more } \\
\text { customers including the poor } \\
\text { Provide the financial resources }\end{array}$ \\
\hline
\end{tabular}


A reason to involve the private sector more may also be the limited efficiency of government organisations, or may be of a financial nature. In some countries governments or government owned enterprises run huge budget deficits and are still not able to deliver the services they should deliver. Inefficient water companies, electricity produced at too high a price, or schoolbooks, which are not regularly updated, are symptoms of an ineffective and inefficient government sector and arguments to try to involve the private sector more, while reserving the role of regulator for the government. The major actors in PPPs in the water and sanitation sector are listed in Table 3.

Table 3 Major actors in PPPs in the water and sanitation sector

\begin{tabular}{llll}
\hline Public sector actors in a PPP & \multicolumn{2}{l}{ Private operators } \\
\hline 1 & National level & 1 & Financial operator \\
2 & Provincial or state level & 2 & Construction companies \\
3 & Local (municipal) & 3 & Water companies and suppliers \\
4 & District level & 4 & NGOs or community-based organisations \\
5 & Ward level authorities & 5 & Private donors \\
\hline
\end{tabular}

The debate on PSI in the water sector is highly politicised. Opponents of PSI in the water sector will never call it PSI, but rather talk about privatisation suggesting that this is a neo-liberal solution leading to a sell off of the water company, but with limited chances of success. Others emphasise that PSI is expensive, encourages corruption, leads to staff layoffs, tariff increase and environmental mitigation (Mathews, 2003).

Through a case study in India we want to find out what are the most important factors in explaining the success and failure of PPPs? Currently new forms of partnering are becoming popular such as twinning, or Water Operator Partnerships (WOPs). They seem to be more trust based on what is sometimes called relational contracting or network governance. To be able to assess their success we first need to know how the old partnerships were doing. However, a more important role for the private sector also means the sector needs to be regulated more closely. Burnham (2001) emphasises that this is, for example hardly the case in France.

\section{Control mechanisms: the need to regulate the private sector}

Private sector involvement has increased in most countries. That raises the issue how to control the private parties involved? Regulation is normally the natural counterpart of PSI. Robinson (1997) describes regulation as a means "of achieving the result of perfect competition whilst avoiding the messy and apparently wasteful process of competition itself". There are however all kinds of possibilities to increase real or pseudo competition leading to better performance.

Competition can be introduced in different ways. ${ }^{9}$ For example, introducing competitive bidding. Robinson (1997) stresses the benefits of greater competition. He suggests market-improving and market-displacing measures. The latter refer to measures which by-pass the market attempting to achieve a result similar to the perfectly competitive outcome by direct government action such as imposing marginal cost pricing (Bahl and Linn, 1992). Private finance also brings in competition (who will provide the 
loan under which conditions) and because it submits water utilities to the discipline of the financial market, which is another type of regulation.

More autonomy for public utilities may also lead to better performance. The government does not need to be directly involved in the production and distribution of water, but could be put at arm length or function indirectly through an independent regulator. For example, in The Netherlands pricing is left to the utility, while in other countries there is often some special institution, for example the regulator, looking at the proposals of the water companies to increase their price. With greater autonomy water companies may get the possibility to hire and fire staff. This can also provide an incentive to the personnel of the water company to make an additional effort. Providing more autonomy is also a reason for asking for accountability and developing independent regulation.

Issues for regulation are allowing one water utility in an area or stimulating the presence of different or even multi-utilities, choosing for price caps or caps on investments and how to assure the quality of water delivery and the respect of health and environmental standards. Pongsiri (2002) stresses the importance of establishing a transparent and sound regulatory framework as a precursor to PSI. Regulation may concern the quality and price, but should also assure respecting contractual relations, arbitration in case of commercial disputes and protection from arbitrary expropriation. Regulation finally requires effective monitoring.

Regulatory approaches also depend on the societal context. They are different for a piped network, for a retail outlet system, or for a mobile distributor of water. For a piped network licenses, tariffs, service quality and bulk water rates are important. For a retail outlet (or point source) operator performance incentives and water quality require attention, while for a mobile distributor of water transport licenses and vehicle regulation may apply and quality control and tariffs play a role.

Countries can opt for an independent regulator defending the interests of society at large, or leave it to the political system or the companies themselves to organise some kind of supervision. There is a need to develop non-ambiguous performance indicators to assess these results. ${ }^{10}$ Key questions for regulation are: what will be regulated, by whom, with which powers to sanction and how to measure performance?

The Office of Water (Ofwat) in the UK is an example of a well-functioning independent regulator (Bakker, 2001) and that experience could be repeated. Bakker (2003) claims that the regulator in the UK is so strong that investing in water companies is now less attractive for the private sector. Some operators are considering stepping out! Even if that would have happened it is not necessarily a bad trend, as long as the expected positive effects of PSI have been achieved (a higher efficiency and the necessary investments). This line of thinking is in line with Mathews (2003) argument that private operators may not be better but may have helped poorly performing public utilities to perform better.

Secondly, the ineffectiveness of regulation has been noted, due to incomplete contracts and the occurrence of information asymmetries. The alternative would be relational contracting where trust is more important. Once the proper regulation is in place, the government can limit itself to creating the conditions for private sector development and controlling through regulation that the private sector will do a good job. Government will have to create a water sector specific regulatory framework and maybe an independent regulator for the drinking water sector, which sees to it that the private sector respects the rules formulated. ${ }^{11}$ 
Because the international private sector tends to be strong, while the local private sector is often not very developed and government officials are not always well-trained there is a clear need in developing countries for regulatory arrangements and capacity building in this field. There is a need to regulate, but regulation can also have negative effects. Under the UK system it can stimulate companies to expand their capital basis too much (Averch and Johnson, 1962). A recent World Bank study warns against the wrong type of regulation, which can be far more onerous in poor countries than in rich ones (Bakovic et al., 2003). Robinson (1997, p.162) also warns for British-style nationalisation (a form of regulation conducted behind close doors) and US-style rate-of-return regulation, which fails to provide incentives to innovate and reduce costs.

Regulatory economics focuses on dealing with competition and all efforts to escape competition, for example by creating cartels. Regulation in the water sector is fundamentally different, because in most cases the sector is a de facto regional monopoly and the objectives are not necessarily the lowest price, but rather security of supply of water of a certain quality. Finally, regulation in the water sector does not only concern the economic and financial aspects, but also health and environmental considerations. Regulation could alternatively be considered as a way to solve the principal agent dilemma. There are only two sources of discipline for private companies: investor imposed discipline or government imposed discipline.

\section{Factors influencing the success of PPPs}

A number of mergers in Europe have pointed to the need of creating a level playing field and uniform legislation and regulation. Some major barriers to successful PPPs are the long planning-horizon, the complexity of various projects and cultural differences between partners. Jamali (2004) identifies critical success factors and policy requirements for successful PPP implementation and mentions among other factors: trust, openness, fairness and mutual respect. No weight is given to these factors. The governance structure of the private water companies or public utilities finally matters. Are the conditions in place to assure good governance, accountability and transparency?

Perrot and Chatelus (2000) summarise important variables for the success of private capital in the infrastructure sector at the macro-economic and at the project level. We have added in Box 2 important factors based on van Dijk and Schwartz (2004). The box summarises the conditions for success of private capital for water and sanitation units and serves as a framework for the Indian case study.

To evaluate the effects of a more commercial approach to water, we first need to know what the objectives of such change were. The literature does not always agree that reforms are undertaken to increase the efficiency (that is what the economists want), or to extent the service areas (that is often what the politicians promised), or to achieve a better cost recovery (the dream of the financial managers), while this does make a difference. The results almost everywhere of more PSI are increases in the price of water, since this is a relatively easily applied instrument to achieve better performance. Improved coverage and better cost recovery are more difficult to achieve. 


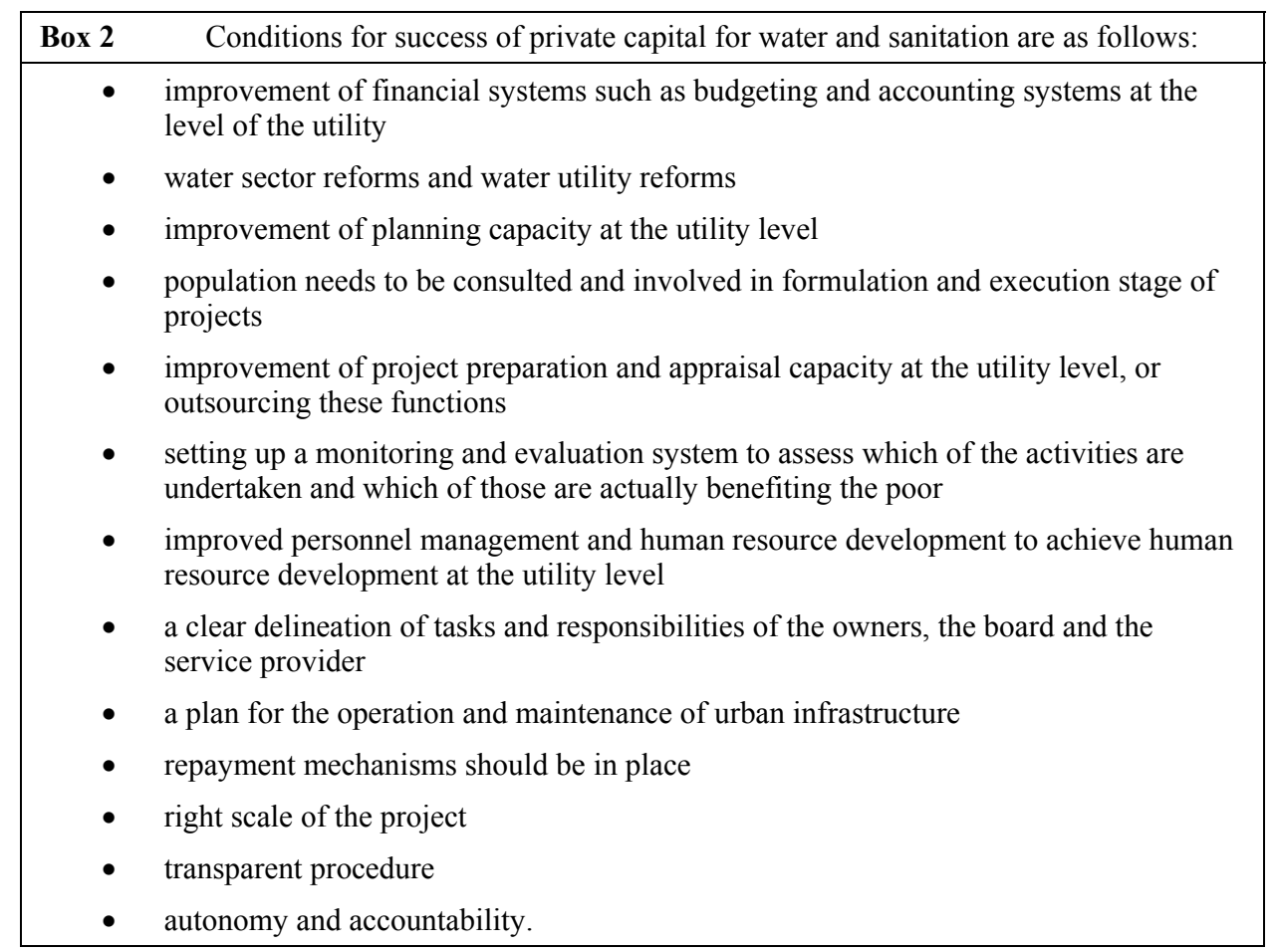

Sources: FIRE (1996), Perrot and Chatelus (2000), van Dijk and Schwartz (2004)

\section{PPP and achieving the MDGs in India}

India has adopted a strategy of decentralisation and devolution for water supply and sanitation and translated it into national programmes. The experiences from these programmes are also relevant for other countries, which have decentralised operational responsibilities and resources for the water and sanitation sector to local governments. They are especially relevant in the light of the global efforts to meet the new MDGs, which the United Nations set in their plenary meeting on 8 September 2000 and at the World Summit on Social Development in 2002 in Johannesburg. For water and sanitation these are to halve, by 2015, the proportion of people who have no access to safe drinking water and/or basic sanitation.

Whether India can achieve the MDGs is one of the main issues discussed in Sijbesma and van Dijk (2006). India has done very well in improving the access of its population to better drinking water. Coverage went up from 31 in rural areas and $77 \%$ in urban areas in 1980 to 80 and $94 \%$ in 2000 . Factors contributing to this success were the priority to drinking water supply in the national policy, with substantial allocations under consecutive Five Year Plans, and a combination of national and state programmes. Bilateral and international cooperation also played a role. However, these achievements are under threat. In the first place, water is a social and an economic good according to the so-called Dublin principles. However, people need to get used to considering good water supply as something requiring investments that need to be paid back. Secondly, 
although increased irrigation coverage has made India self-sufficient in food production, it has also brought new problems: water shortages, lower groundwater levels, soil salination, inequitable water distribution between users and conflicts about water between Indian states and between India and its neighbours. Also the lack of treatment of wastewater and the installation of pit latrines in high water table areas cause bacteriological contamination of surface water and shallow groundwater.

According to Satyanaranya (2006) only 50\% of the population in urban areas in India had water taps within the compound. Approximately $65 \%$ of households had some sort of water facility, be it a tap, well or hand pump within the compound. The remaining $35 \%$ of the population depended on outside sources. On the sanitation front, $61 \%$ of households had access to either pit latrines or water closets.

A further problem is the poor reliability of water deliveries. Water shortages in rural areas range from 4 to $30 \%$ and in urban areas from 2 to $30 \%$. Achieving coverage for the last $15 \%$ in the rural areas and maintaining universal access has proven unexpectedly difficult. In some states, access to improved water supply is less than $50 \%$. Nation-wide, $26 \%$ of the rural population still relies on open wells. Financially, budget allocations of Rs. 2.5 billion/year for operation and maintenance of the existing water supplies are less than $10 \%$ of the estimated actual requirements of Rs. 29 billion, excluding rehabilitation, repairs and extension. ${ }^{12}$ Expenditures of the centre and states are vastly inadequate to meet the requirements for sustaining existing water supplies. PPPs can make a contribution to the achievement of the MDGs, given the financial and skill bottlenecks for the fulfilment of the MDGs in the water and sanitation sector. In Asia PPPs are becoming more and more common.

\section{Progress with PPPs in India}

In India PPPs are considered an alternative way of financing initiatives, which would otherwise not be realised. Involving the private sector through PPPs is one option for achieving the MDGs, other options will be mentioned below. Sometimes the term PPP is used for a large range of initiatives to involve the private sector, including financing through the private sector, or using money from private individuals. BOT contracts are very common in the power generation sector (Lindfield, 1998). These experiments generated a number of valuable lessons.

Some PPP experiments led to better utility performance but others did not. Hence handing over managerial responsibility to a for-profit entity is no guarantee for better utility performance (Braadbaart, 2002). Contracts between governments and private providers sometimes, but certainly not always, produced better outcomes than pre-existing arrangements between governments and public providers (Braadbaart, 2002; World Bank, 2002). The challenge is to identify the conditions under which they will be successful.

In India State governments are responsible for urban development and local governments are considered to be responsible for water, sanitation and sewerage. The 74th Constitutional Amendment in India promotes decentralisation and suggests strengthening and establishing State Level Finance Institutions (SLFIs) to help states to finance their investments (van Dijk, 2004). A number of SLFIs has been created in India since 1992. Their mandate is to provide financial assistance (loans and advances) to Urban Local Bodies (ULB) for financing infrastructure and services. The SLFIs 
were often used to channel Central Government grant money to municipalities. Later also HUDCO loans were channelled through them. ${ }^{13}$ Private or semi-public institutions have also indicated that they are willing to finance urban infrastructure.

The response of the central government to the chance of not achieving the MDGs has been to introduce new water policies and programmes. These policies stress the involvement of people in project planning and the management of water resources. However, the national law can only give general guidance. Surface water falls under the jurisdiction of the state governments, while groundwater belongs de facto to the owners of the land, which had led to serious depletion and negative impacts for poor people and women relying on public sources. The Panchayat Act of 1992, laid down in the 73rd and 74th Amendment to the Constitution, shifted the responsibilities for water supply and sanitation, along with 27 other responsibilities from state agencies to local governments.

This created the opportunity for community-managed water supply and sanitation and PPP. Government water supply agencies undertook pilot projects for community managed water supply and sanitation with bilateral and World Bank funding. These initial pilots were followed by a countrywide pilot project planned and financed by the central government and implemented nation-wide in 63 districts. In these districts, individual Panchayats could plan, implement and run their own improved community water supplies with $90 \%$ direct funding from central government if they contributed $10 \%$ of the investment costs and thereafter operated and managed the systems themselves. ${ }^{14}$ Before the national pilot project was finished and evaluated, the Indian Government upgraded it to a national programme.

\section{Urban PPPs in India}

In urban areas more efforts have been made to promote different approaches to infrastructure provision, often with PSI. PPPs were used to build roads in Rajasthan and to improve CG Road in Ahmedabad (Gujarat), but also to finance different urban water and sanitation projects (FIRE, 2000; FIRE, 2001; FIRE, 2002). World Bank (2005: 73) also stresses that PPPs can play an important role in meeting infrastructure demand. A survey undertaken by the World Bank showed almost 90 PPP projects in the transport and urban sectors that were operational, or at an advanced stage of implementation (total project costs around Rs. 339.5 billion). Most PPP projects in infrastructure concerned roads and bridges $(74 \%)$, with urban projects second $(13 \%)$. Few concerned ports $(9 \%)$, airports $(2 \%)$ and railroads $(2 \%)$. The picture changes substantially if project cost of awarded PPPs are taken as the criterion. Now ports get more than half the money $(55 \%)$, roads and bridges ( $36 \%)$, airports $(5 \%)$, urban projects $(3 \%)$ and railroads $(2 \%)$.

However, according to the same source, over the last decade private investment in infrastructure has averaged around 1\% of GDP in India, which is small compared to some other developing countries. In China, for example private investment accounted for around $10 \%$ of total investment in the road sector.

World Bank (2005, p.73) concludes that India with its recent moves to attract a higher level of investment commitments to private infrastructure scored with almost 10 billion dollar higher than either Brazil or China in 2004. That money still has to find its way to the water sector.

In the operationalisation of new sector-related policies and programmes, the state governments and their institutions play a crucial role. Sijbesma and van Dijk (2006) 
summarise these experiences in India, and provides an agenda of research that can support the large-scale application of water supply and sanitation initiatives managed by rural communities with support of organisations at above-community levels. Several other institutional settings for implementation evolved on the ground and are discussed in the book. For example, community projects under decentralised local government (district) programmes and under programmes by Non-Governmental Organisations (NGOs) besides PPP. ${ }^{15}$ There have been a number of positive experiences for all these models. At the same time, implementation of locally managed water supply and sanitation has been limited, slow and far from ideal and there is a risk that the MDGs will not be achieved in India. The response of state bureaucracies to the scaling up of community planned and managed services has been disappointing. Lessons gained in experiments under bilateral and multi-lateral cooperation are reflected in policy and programmes at national level, but the states have been reluctant to mainstream them in their own policies and programmes.

The major challenges in India to meet the MDGs are political and institutional, rather than purely financial or technical. Politically, there is the challenge that political parties at the state and national level embrace the local government reforms not just in words, but also in deeds. Major institutional bottlenecks for the new policy and programme to meet the MDGs for (sustained) access (and use) in the water sector remain the reluctance of the states to transfer funds, functionaries and functions as well as authority to Panchayats (a lower tier of government). It is necessary to build local capacities for Panchayat-managed water supply and sanitation activities: of the elected officials, the water and sanitation committees and the user assemblies.

In a number of communities, the formal and informal often small-scale private sector supplies drinking water to supplement or replace poorly functioning public services. Either the consumers have formed their own society, which builds and runs a private water supply or private entrepreneurs responded to local demand with the silent consent of the municipality. ${ }^{16}$ Furthermore, contractors have assisted communities to construct water supplies under the Sector Reform project (Kumar, 2006).

Privately managed small-scale community water supplies are also more effective and efficient as reported in the case studies of Sankar (2006), Reddy and Dev (2006) and James and Moriarty (2006). Adjustment of connection costs to their income patterns made joining more affordable for the poor. Stimulating NGO programmes is another model. Many of them (but not all) have faith in village capacities and the skills to help communities undertake their own projects with gender and social equity. The Swajal project has shown that NGOs, which are shortlisted for their social experience and managerial capacities, had no problems in also engaging engineers for helping local women and men make informed technology choices and take up technical tasks. However, without government financing of capital costs (90\% under Swajaldara), the scope of work of NGOs in the rural water sector is limited. In Gujarat, for example the local NGO Utthan could assist 108 villages in four districts and took up 28 watershed development projects. Officially, Gujarat has only 1532 un- or partially served communities, so in that case 108 would be substantial. However, these statistics leave out many communities with perennial water shortage.

The experiences reported in Sijbesma and van Dijk (2006) show that piped water supply operated by private entrepreneurs or by a user association provided a better service to the middle and upper classes, but excluded the poor. In Water Sector Reform projects in India, private contractors have sometimes made the designs and paid the 
$10 \%$ community contributions for interested communities. The contractors recovered these costs and increased their own profits by designing costlier schemes and including speed charges. Overall, experiences with small enterprises have been more positive than with larger companies and financing organisations.

Letting communities choose their own supporting and implementing agencies, be they from government, NGOs or private sector is another option. Government financing of the investment costs would then include compensation for the organisations that assist communities in making the proposal and designs.

Technical assistance should be provided to communities in combination with rehabilitation, upgrading and new construction to achieve a reliable, equitable and holistic system of community water supply for drinking, cooking, hygiene and basic productivity within households, along with improved sanitation. Technology options and service levels should be acceptable and manageable for different types of communities and households. Socially, the technical assistance teams could devise, test and document ways to reach the poor and ensure that women and poor women have equal shares in decisions and benefits. Financially, they would help communities to achieve equitable sharing of partial community financing of capital costs and full financing of operation and maintenance cost. The financing systems would be locally specific and planned and include accountability to the users, including women and poor households. Environmentally, they would help communities to develop adequate management of water and waste disposal throughout local catchment areas with representation of all stakeholder groups according to gender, class and water uses. Institutionally, the aim would be to achieve effective and equitable management of services with accountability for performance including to the poor and women.

Government financing for NGO programmes for community-managed water supply and sanitation would be another model. NGO financing could be tried alongside existing modalities. The strength of such an approach would be the social expertise and holistic water resources and catchment approaches, which are missing in state water agencies.

\section{Successes of PPPs in the water sector in India}

Drinking water supply activities are not integrated with water conservation and watershed programmes and they have not been made to involve the private sector in water and sanitation projects (Reddy, 2006). The new approach of increasing PSI is analysed in Sijbesma and van Dijk (2006) and a succinct overview is given by Satyanaraya (2006). The well-known cases of using new sources of finance for environmental infrastructure (including drinking water and sanitation) are located in Andhra Pradesh (APUSP, 1998; FIRE, 2001; FIRE, 2002) and in Gujarat (Tripathi, 1998; FIRE, 2000; Hesselberg, 2002; Ray, 2003). These cases are among the well-documented early experiences and help to gain insight in the factors determining the success of this approach and to draw some general conclusions about the role of PPPs in basic service delivery and its impact on the poor. The critical question is whether they have contributed to India's split development: progress for the middle classes, but stagnation for the poor?

The research presented in Sijbesma and van Dijk (2006) shows that at the macroeconomic level the following factors are important for the success of PPPs in India: 
- stable macro-economic context: no high inflation or rapid changes in the rate of exchange or the rate of interest

- political commitment

- a good regulatory framework, which is in place before the project actually starts

- pro-poor institutional arrangements

- functioning capital markets and an appropriate legal framework.

It boils down to the question: has the government created an enabling environment for PPPs? Gujarat was, for example one of the first states in India to create a legal basis for PPPs. At the meso-level the following factors are important: participation of the target group in project preparation and putting in place some system for cost recovery. Finally, at the project or micro-level there should be:

- customer and market orientation

- community involvement in the execution

- proper identification and allocation of the risks

- promotion, education and awareness raising.

This list helps to define the roles and responsibilities of the partner. The positive effects of infrastructure built by different levels of government and of the expenditures of local governments for the poor have been assessed numerous times (World Bank, 2002; World Bank, 2006). Usually, there is currently no infrastructure and hence it is necessary to develop services and infrastructure also for the poor and tailored to the needs of the poor. We should identify in particular conditions for the success of that kind of PPP in the water and sanitation sector for the poor. The conceptual links are summarised in Figure 1.

Figure 1 Impact of PPP supported urban infrastructure on poverty

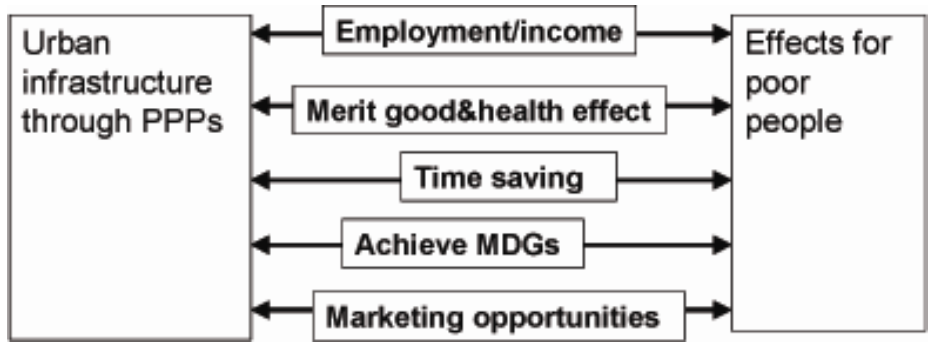

Infrastructure delivers inputs to farms, helps to market agricultural produce, distributes raw materials and facilitates both domestic and international trade. There is a direct link between economic development and the growth rate of infrastructure. ${ }^{17}$ One can observe that more infrastructure and transport in the rural areas in India does contribute to development. A lot of money is spent on improving the infrastructure and transport and the link with development has been shown in World Bank (2006). Transport contributes to poverty alleviation by assuring cost-effective transport of goods and people. It also links a country to the global economy and assists neighbouring communities to connect 
to the world. In its current forms, PPP have been partial solutions. Cases of partnerships with the formal and informal sector have been few and far and have pros and cons. The objective of the national dialogue process as stimulated by the European Union Water Initiative (EUWI) is usually to make water governance more effective and build institutional capacity in developing countries for such a different approach to carrying out water and sanitation projects.

\section{Promote a PPP dialogue in India}

If a dialogue between different parties in India could be organised before actually implementing PPP projects in the water and sanitation sector with support of the private sector the chances of success of such projects would be enhanced. The dialogue may help to improve the understanding between parties. It will help to identify key areas for action and to raise the importance of the water and sanitation sector in the Poverty Reduction Strategy Paper (PRSP). The focus should be on investment for the poor.

In fact two types of dialogue can be distinguished. In the short run the objective may be to identify the problems and to brief relevant parties about the need to do something, to give an overview of the water and sanitation sector and develop a country action plan. Such a plan could specify the service-delivery targets for achieving the water and sanitation millennium goals. Secondly, in the long-term dialogue processes may continue until 2015 the year the MDGs have to be achieved. These dialogues could lead to road maps how to achieve these MDGs and should lead to the harmonisation with other activities. Harmonisation is a big issue. It means more cooperation, between donors, and between different layers of government and between representatives of the major stakeholders. In short, it requires a dialogue. Road maps need to be developed in steps, where tracking progress is important. It requires to:

A Accelerate and deepen institutional reforms, including the legal and institutional framework, the pricing policy and demand responsiveness. Strengthen capacity and mobilise more and smarter finance from a broadened base. There is a need for good practice in a number of key areas which are as follows:

1 sector coordination

2 large scale demand responsive rural water supply programmes with strong Operations and Management (O\&M) strategies

3 reaching the urban poor

4 raising the profile for this approach.

B Be used as a guiding principle; there is a need to:

1 have steadfast political commitment

2 clarify the lead agency

3 forge a coalition of the willing

$4 \quad$ link MDG road map with the budgeting in the systems in the country.

C Follow the sequence:

1 start with a water supply and sanitation MDG review, a country study

2 begin the national consultation and organise the national consultation, for example a national workshop 
3 prepare a consensus plan

4 the road map or action plan to achieve the MDGs brings together the priorities and calculates the financial implications

5 start implementing it

6 monitor whether a real new situation is developing.

Issues in the case of the country dialogues are how to get the ownership of the projects in the country concerned? How to involve other donors and providers of finance? What is the role of civil society? How can the dialogue contribute to more effective interventions in the water and sanitation sector? The implication of this approach is that the dialogue is a costly and long-term process. The dialogue should also involve the private (commercial and non-commercial) sector. Such a dialogue may result in road maps of how to achieve the MDGs. Lessons learned in the framework of the EUWI concerning the PPP country dialogue so far are as follows: ${ }^{18}$

1 the different parties have to accept the role of an intermediary

2 they need to see some role for themselves to justify their involvement

3 there should be a national owner and local stakeholders should play an important role

4 parties should be committed from the start, but realise that a dialogue is not enough

5 hence look for possibilities to finance results of the dialogue

6 ownership is important and the consultation process takes time.

\section{Conclusions}

In this special issue Schouten and van Dijk pointed to a proliferation of management models in the European water market, from municipal water corporations to communitymanaged water supply and from public utilities to private providers. It will not be useful to impose one model for all countries, rather the different models may converge towards a model with more outsourcing and closer regulation. At a lower level the governance structure of the private water companies or public utilities matters..$^{19}$ Are the conditions in place to assure good governance, accountability and transparency?

Private Sector Involvement is playing a critical role in assisting countries to obtain the necessary infrastructure. Often PPPs are playing a critical role in assisting countries to obtain the necessary infrastructure. It is important to learn from PPP case studies so far, for example through the publications of the FIRE project, which in the case of India facilitated the development of solid waste, roads, urban renewal and water projects (FIRE, 1996). PPPs are a flexible instrument, which allows developing tailor made solutions.

At the same time this flexibility makes it a difficult to evaluate the instrument and to identify the conditions for success. Often the PPP cannot even be formed, because no parties can be found, or the partners can be very secretive, which does not result in the desired transparency. More research using case studies helps to identify what the most important factors are, which explain the success and failure of PPPs.

A PPP dialogue process helps to make water governance effective, to build institutional capacity in developing countries, but on top of that to involve other 
stakeholders, namely private sector participants in achieving the development goals. The dialogue may also help to improve the understanding between parties as it will help to identify key areas for action and to raise the importance of the water and sanitation sector in the PRSP. The challenge will be to keep the focus on investment for the poor.

The objective of the PPP dialogue in India would be to involve all stakeholders, also private sector participants, in achieving the MDGs. A national dialogue will help to improve the understanding between parties as it will help to identify key areas for action and to raise the importance of the water and sanitation sector in the states concerned.

Infrastructure is a necessary, but not a sufficient condition for development. In this contribution we identified several bottlenecks, but also some interesting opportunities and initiatives to improve the current situation. The question now is how the new opportunities created by an improved infrastructure are taken up by citizens, the local businessmen in the formal and informal sector and how the authorities in the framework of decentralisation use the new opportunities, which come into existence through (PPP financed) infrastructure. We consider that PPPs do not necessarily imply a split development.

PPPs may not have been very successful in the water sector; however they have stimulated governments to put a regulatory framework in place. As shown in the case study of Zambia, such a regulation or regulator may help to improve the situation in the water sector. PPPs tend to fail more often in the big cities than in the smaller ones.

For PPPs to be successful certain conditions need to be in place. The necessary reforms need to be undertaken, some kind of regulatory system should be in place and it is important to set up a monitoring system to be able to correct the course if it does not go in the desired direction. The experience shows that the period of a concession contract tends to become shorter to allow adjustment if the desired results are not produced. Secondly, the big operators such as Suez and Bi-water have become more reluctant to finance the water sector in developing countries. Still money is needed and governments cannot always supply the funds. PSI is a good alternative and donors may be willing to support certain PPPs, if the conditions are in place and to help countries achieve their MDGs.

\section{Acknowledgements}

The research has been partially funded by the Switch project, which receives support from the European Union (www.switchurbanwater.eu).

\section{References}

APUSP (1998) Urban Services for the Poor, Draft Final Report, DHV-HIS, Hyderabad.

Averch, H.A. and Johnson, L.L. (1962, December) 'Behaviour of the firm under regulatory constraint', American Economic Review, Vol. 52, No. 5, pp.1052-1069.

Bahl, R.W. and Linn, J.F. (1992) Urban Public Finance in Developing Countries, IBRD, Washington.

Bakker, K.J. (2001) 'Paying for water: water pricing and equity in England and Wales', Transactions of the Institute of British Geographers, Vol. 26, No. 2, pp.143-164.

Bakker, K.J. (2003) 'From public to private to ... mutual? Restructuring water supply governance in England and Wales', Geoforum, Vol. 34, No. 3, pp.359-374. 
Bakovic, T., Tenebaum, B. and Woolf, F. (2003) Regulation by Contract, A New Way to Privatize Electricity Distribution, IBRD, Washington.

Braadbaart, O. (2002) 'Private versus public provision of water services: does ownership matter for utility efficiency?' Journal of Water Supply, Research and Technolgy-AQUA, Vol. 51, No. 7, pp.375-388.

Burnham, J. (2001) 'Local public private partnerships in France: rarely disputed, scarcely competitive, weakly regulated', Public Policy and Administration, Vol. 16, No. 4, pp.47-61.

FIRE (1996) Municipal Bond Market for Urban Infrastructure, FIRE Project, New Delhi.

FIRE (2000) Ahmedabad Municipal Bond Experience, FIRE Project, New Delhi, 4 pages.

FIRE (2001) Lessons Learned from the Ahmedabad Municipal Bond, FIRE, New Delhi.

FIRE (2002) Innovative Programs to Improve Access of the Poor to Urban Environmental Services in Andhra Pradesh, FIRE Project, New Delhi.

Franceys, R. and Bos, A. (Eds) (2003) Incentives for Water Utilities to Serve the Urban Poor, IMO Working Group, Water Supply and Sanitation Collaborative Council, Geneva.

Hesselberg, J. (Ed.) (2002) Issues in Urbanisation, Rawat Publications, Jaipur, 224 pp.

Jamali, D. (2004) 'Success and failure mechanisms of PPPs in developing countries, insights from the Lebanese context', The International Journal of Public Sector Management, Vol. 17, No. $4 / 5$, pp.414-431.

James, A. J. and Moriarty, P. (2006) 'PPP water partnerships: the small and local view form India', in: Sijbesma, C. and van Dijk, M.P. (Eds) (2006) Water and Sanitation, Institutional Challenges in India, Manohar, New Delhi.

Jaspers, F. (2003) Institutions for IWRM. Delft: UNESCO-IHE, training manual.

Kirkpatrick, C. and Parker, D. (2004) 'Regulatory impact assessment and regulatory governance in developing countries', Public Administration and Development, Vol. 24, No. 4, pp.333-344.

Kumar, Y. (2006) 'Local self-government: experiences in Madhya Pradesh and challenges ahead', in: Sijbesma, C. and van Dijk, M.P. (Eds) (2006) Water and Sanitation, Institutional Challenges in India, Manohar, New Delhi.

Lindfield, M. (1998) Preparing Markets for Private Financing of Urban Infrastructure, PhD thesis, Erasmus University, Rotterdam.

Mathews, J. (2003) PPPs in Waste Water Treatment in the US, MSc thesis, UNESCO-IHE, Delft.

Nijkamp, P., van der Burch, M. and Vindigni, G. (2002) 'A comparative institutional evaluation of PPP in Dutch urban land use and revitalisation projects', Urban Studies, Vol. 39, No. 10, pp.1865-1888.

Perrot, J-Y. and Chatelus, G. (Eds) (2000) Financing of Major Infrastructure and Public Service Projects, Ponts et Chaussees, Paris.

Pongsiri, N. (2002) 'Regulation and public private partnerships', The International Journal of Public Sector Management, Vol. 15, No. 6, pp.487-495.

Prasad, N. (2006) 'Privatisation results: PSP in water services after 15 years', Development Policy Review, Vol. 24, No. 6, pp.669-692.

Ray, C.N. (2003) Liberalization and Urban Social Services, Rawat Publications, Jaipur.

Reddy, K.P. (2006) 'Water sector reform policy and operationalization: experiences in Gujarat', in: Sijbesma, C. and van Dijk, M.P. (Eds) (2006) Water and Sanitation, Institutional Challenges in India, Manohar, New Delhi.

Reddy, V.R. and Dev, S.M. (2006) 'Drinking water and sanitation in India, need for demand management structures', in: Sijbesma, C. and van Dijk, M.P. (Eds) (2006) Water and Sanitation, Institutional Challenges in India, Manohar, New Delhi.

Robinson, C. (1997) 'Introducing competition into water', in: Beesley, M.E. (Ed.) (1997) Regulating Utilities, Broadening the Debate, Business School and Institute for Economic Affairs, London. 
Sankar, U. (2006) 'Financial and economic sustainability: PPP', in: Sijbesma, C. and van Dijk, M.P. (Eds) (2006) Water and Sanitation, Institutional Challenges in India, Manohar, New Delhi.

Satyanaraya, V. (2006) 'Sustainable urban services and private sector participation: an Indian experience', in: Sijbesma, C. and van Dijk, M.P. (Eds) (2006) Water and Sanitation, Institutional Challenges in India, Manohar, New Delhi.

Sijbesma, C. and van Dijk, M.P. (Eds) (2006) Water and Sanitation, Institutional Challenges in India, Manohar, New Delhi.

Tripathi, D. (1998) Alliance for Change, a Slum Upgrading Experiment in Ahmedabad, McGraw-Hill, New Delhi, 193 pages.

van Dijk, M.P. (2004) 'The role of financial institutions and markets in urban development in India, with examples from Karnataka and Gujarat', in Gupta, K.R. (Ed.): Urban Development in the New Millennium, Atlantic, New Delhi, pp.229-240.

van Dijk, M.P. (2006a) Managing Cities in Developing Countries, The Theory and Practice of Urban Management, Edward Elgar, Cheltenham.

van Dijk, M.P. (2006b) Urban Rural Dynamics in Tanzania, Report for the World Bank, UNESCO-IHE, Delft.

van Dijk, M.P. and Schwartz, K. (2004) Modes of Engagements, Report on Public Modes of Engagement, World Bank, Washington.

World Bank (2002) World Development Report, Oxford, New York.

World Bank (2005) Social Services in India, World Bank Office, New Delhi.

World Bank (2006) Transport and Poverty, World Bank Office, Dar es Salaam.

\section{Notes}

1 The Financial Times (26 July 2006) notes that investors are putt off by weak infrastructure in India.

2 The FIRE project intended to create possibilities for local governments in India to gain access to the local and international capital markets to allow them to finance their infrastructure. On FIRE's website we can find answers to questions such as: What are the pre-requisites to make PPPs a success? What kind of legal framework is required? And: where would the funds come from?

3 An agreement between the municipality and a local NGO in Bamako, the capital of Mali has been reached and is an example of a PPCP:

- the young people from the neighbourhood collect waste in certain neighbourhoods for a fee

- they use donkey carts as an appropriate technology for this purpose.

4 A second definition provided is 'a relationship resembling a legal partnership and usually involving close cooperation between parties having specified and joint rights and responsibilities'.

5 Privatisation in the broad sense means PSI, but it is often used in the narrow sense of divestiture.

6 http://rru.worldbank.org/PPI.

7 Legal forms used in the case of PPPs are the BOT and its variants (Build-Operate and Own, BOO and Build-Operate and Lease, BOL), joint ventures and concessions.

8 Instruments such as bonds, shares and loans, lease arrangements, micro-finance and subsidies.

9 Competition IN the market (England and Wales), competition FOR the market (concessions in France) and Yardstick or benchmark competition, with or without a regulator (the case in The Netherlands and in Zambia). 
10 For example, the solvency ratio (equity capital as part of total capital); or yield to assets; or number of connections/personnel; or operating revenue as percentage of operational costs and prices charged by the utility for water of different quality and finally indicators for the quality and regular supply of water.

11 This is what World Bank (2002) calls building institutions for markets!

12 One dollar equalled Rs. 45 at the time of the research.

13 HUDCO is the Housing and Urban Development Corporation.

14 In the case of water sector development the contribution of stakeholders may be in kind or in cash.

15 A number of states (such as Karnataka, Gujarat, Tamil Nadu) contract NGOs to run primary health facilities, just like the national tuberculosis programme does. Also the National AIDS Control Organisation operates largely through service contracts to NGOs for targeted interventions, behaviour change activities and other services (World Bank, 2005, p.73).

16 Reddy and Dev (2006) and James and Moriarty (2006).

17 The rehabilitation of physical infrastructure in Tanzania, for example particularly the trunk and regional roads under the Integrated Road Program (IRP) improved significantly marketing networks. Recently the government is working on the privatisation of the railroads, which hopefully leads to an improved functioning and could also be a big boost for the harbour of Dar es Salaam (van Dijk, 2006b).

18 Use has been made of Moriarty's (IRC) presentation in Brussels for the African water and sanitation working group of the EUWI on 18 January 2005.

19 The issue of what kind of institutions we need for good water management may also be called the issue of water governance. Jaspers (2003) defines water governance as "the social capacity to mobilize in a coherent way water resources to achieve sustainable development". This includes the capacity to design publicly accepted policies, oriented towards sustainable development and making effective their implementation through all stakeholders involved. $\mathrm{He}$ indicates that the level of water governance in any society is determined by factors like the existence of consensus, the level of consensus and compliance and the availability of a management system, which enables within a sustainable framework the implementation and follow-up of those policies. 